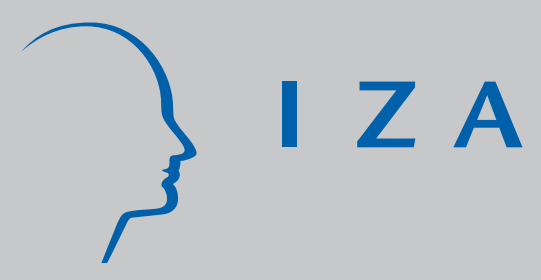

IZA DP No. 4067

Religion and Intimate Partner Violence in Chile: Macro- and Micro-Level Influences

\author{
Evelyn Lehrer \\ Vivian Lehrer \\ Ramona Krauss
}

March 2009 


\title{
Religion and Intimate Partner Violence in Chile: Macro- and Micro-Level Influences
}

\author{
Evelyn Lehrer \\ University of Illinois at Chicago \\ and IZA \\ Vivian Lehrer \\ Urban Justice Center \\ Ramona Krauss \\ University of Illinois at Chicago
}

\section{Discussion Paper No. 4067 \\ March 2009}

\author{
IZA \\ P.O. Box 7240 \\ 53072 Bonn \\ Germany \\ Phone: +49-228-3894-0 \\ Fax: +49-228-3894-180 \\ E-mail: iza@iza.org
}

\begin{abstract}
Any opinions expressed here are those of the author(s) and not those of IZA. Research published in this series may include views on policy, but the institute itself takes no institutional policy positions.

The Institute for the Study of Labor (IZA) in Bonn is a local and virtual international research center and a place of communication between science, politics and business. IZA is an independent nonprofit organization supported by Deutsche Post Foundation. The center is associated with the University of Bonn and offers a stimulating research environment through its international network, workshops and conferences, data service, project support, research visits and doctoral program. IZA engages in (i) original and internationally competitive research in all fields of labor economics, (ii) development of policy concepts, and (iii) dissemination of research results and concepts to the interested public.
\end{abstract}

IZA Discussion Papers often represent preliminary work and are circulated to encourage discussion. Citation of such a paper should account for its provisional character. A revised version may be available directly from the author. 


\section{ABSTRACT}

\section{Religion and Intimate Partner Violence in Chile: Macro- and Micro-Level Influences ${ }^{*}$}

The Catholic Church has had a strong influence on the Chilean legal and social landscape in ways that have adversely affected victims of intimate partner violence; e.g., it succeeded until just five years ago in blocking efforts to legalize divorce. At the same time, quantitative studies based on survey data from the United States and other countries show a generally favorable influence of religion on health and many other domains of life, including intimate partner violence. The present study explores the puzzle posed by these seemingly opposing macro- and micro- level forces. Results based on data from the 2005 Survey of Student WellBeing, a questionnaire on gender based violence administered to students at a large public university in Chile, show that moderate or low levels of religiosity are associated with reduced vulnerability to violence, but high levels are not. This non-linearity sheds light on the puzzle, because at the macro level the religious views shaping Chile's legal and social environment have been extreme.

JEL Classification: $\quad$ Z12, J12, J16

Keywords: intimate partner violence, religion

Corresponding author:

Evelyn Lehrer

Economics Department (M/C 144)

University of Illinois at Chicago

601 South Morgan Chicago, IL 60607

USA

E-mail: elehrer@uic.edu

\footnotetext{
* We are indebted to William Sander and two anonymous referees for many helpful comments on earlier drafts of this paper. We also received valuable suggestions from participants at the meetings of the Illinois Economics Association, October 2007, Chicago.
} 


\section{Religion and Intimate Partner Violence in Chile: \\ Macro- and Micro-Level Influences}

\section{Introduction}

Dating back to the birth of the country as an independent state, the Catholic Church has been extremely influential in Chile. During the period of the Pinochet dictatorship (1973-1990) the Catholic Church broke its traditional alliance with the elite and turned to defend the interests of the poor, a segment of the religious market where competition from Protestants had become particularly fierce (Gill 1998). A solid supporter of human rights during this stage of Chilean history, the Catholic Church emerged as a particularly strong institution after the end of the military regime, with increased influence and moral leverage. Subsequently it was able to use its heightened strength to shape the legal and social landscape in ways that ironically were often deleterious to women--victims of gender-based violence in particular. The Catholic Church has succeeded in keeping abortion illegal in the country to this date even in cases of rape or when the woman's life is at risk, and was also able to block efforts to legalize divorce until just five years ago (Blofield 2001; Htun 2003; Blofield and Haas 2005). Lacking the resources to obtain an annulment and get around the legal prohibitions against divorce, low income women faced major obstacles to escaping spousal abuse; in addition, when they were able to proceed with an informal dissolution of their marriage, they received no child support (McWhirter 1999, Htun 2003). ${ }^{1}$

At present, Chilean universities lack prevention/ response programs to address problems of gender based violence, and adequate education and health care programs to address the sexual and reproductive needs of youths have not been set up. The failure of 
the Chilean government to establish policies in these areas has been attributed to the resistance of the politically conservative sectors of Chilean society, principally the Catholic Church (Haas 1999; Committee on Economic, Social, and Cultural Rights 2004; Casas 2004). In addition, rooted in religious traditions, Chile's Civil Code views marital unions as headed by the husband-- he is in charge of administering the spouses' joint property and that owned by his wife (Neuwirth 2005).

The macro-level literature reviewed above suggests that religion has had an adverse influence from the perspective of victims of gender based violence in Chile because of its impact on Chilean laws, policies, and the overall social environment. This conclusion stands in marked contrast to findings from numerous quantitative studies based on surveys conducted in the U.S. and other countries which show that, although there are exceptions, religion is generally associated with positive effects on many domains of individuals' lives. In the adult population, the benefits include better physical and mental health (Koenig et al. 2001; Waite and Lehrer 2003) and better economic outcomes (Gruber 2005; Chiswick and Huang 2007). Among youth, they include a lower probability of risky behaviors, including substance abuse and early sexual debut (Donahue and Benson 1995; Resnick et al. 1997; Bearman and Bruckner 2001; Meier 2003); more negative attitudes toward premarital childbearing (Marchena and Waite 2003); better relations with their parents (Pearce and Axinn 1998); a lower likelihood of developing close friendships with peers who have problems with substance use (Bahr et al. 1998); and better educational outcomes (Freeman 1986; Regnerus 2000; Muller and Ellison 2001; Lehrer 2006, 2009). Young women who have some religious involvement have also been found to be less likely to be victims of intimate partner violence (IPV) in 
their dating relationships (Makepeace 1987; Howard et al. 2003), reflecting the reduced vulnerability associated with their generally healthier, less risky lifestyles (Gover 2004). Related research based on married and cohabiting couples has found that attendance to religious services is associated with less perpetration of IPV by both men and women (Ellison et al. 1999; Ellison and Anderson 2001) and also less victimization in women (Ellison et al. 2007).

In this study we attempt to shed light on the seemingly countervailing macro- and micro- level influences of religion on IPV in Chile. The empirical analysis uses data from the 2005 Survey of Student Well-Being, a questionnaire administered to students at a major public university in Santiago. The survey included detailed questions on psychological, physical, and sexual violence with a focus on victimization (as opposed to perpetration). The main objective of the survey was to provide the first estimates of the prevalence of gender-based violence in college students in Chile and to study risk factors for such violence (Lehrer et al. 2007a; Lehrer et al. 2007b). ${ }^{2}$ The present study takes advantage of the fact that the survey included a question on the students' frequency of attendance to religious services at age 14, thus providing a unique opportunity to quantify the relationship between this variable and young women's subsequent risk of being a victim of IPV in dating relationships.

\section{Theoretical Framework}

As noted above, numerous studies have documented an association of some religious involvement with a wide range of beneficial outcomes. It has been suggested that causal mechanisms that may explain these relationships include: (a) a social capital 
effect, whereby religious participation integrates people into supportive networks; (b) a regulative effect, whereby the teachings of the religion encourage healthy, constructive conduct; and (c) the psychological benefits associated with participation in religious activities (Waite and Lehrer 2003; see also Smith 2003). In the case of young women, these mechanisms are expected to lead to healthier, less risky life styles, and thus indirectly, to reduced vulnerability to IPV in their dating relationships.

Although there are some exceptions (e.g., Ellison et al. 1999), previous analyses of how religious participation affects various outcomes have generally specified participation either as a continuous variable or as a simple dichotomy for high vs. low/zero frequency of attendance to religious services. A recent study specifies it as a set of dummy variables and thus allows for the possibility of non-linearities (Chiswick and Huang 2007). Examining the effects of religious participation on earnings based on data from the 2000/2001 National Jewish Population Survey, the authors find that individuals who attend religious services weekly have significantly higher earnings than those who attend less frequently or not at all, supporting the hypothesis that some religious involvement has a beneficial effect on labor market outcomes; however, those who attend services more than weekly have lower earnings than those who attend weekly. The authors suggest that beyond a point, time and effort allocated to religious activities may begin to crowd out time and effort that could be oriented to labor market activities, and that discrimination in the labor market and lifestyle restrictions associated with the Orthodox denomination may also play a role.

A non-linearity may also be present in the relationship between frequency of attendance to religious services and women's vulnerability to IPV in dating relationships, 
for different reasons. The argument for a protective effect is that the healthier lifestyles of youths raised with some involvement in religion make them less vulnerable to victimization. However, a review of literature on the religion - IPV connection at the individual level in several countries, suggests that the protective effect may not be present, and the effect may even be adverse, at the high levels of religious participation typically associated with conservative theological beliefs.

Mixed results have emerged from this literature. In a large-scale study of U.S. married and cohabiting couples, Ellison et al. (1999) found an inverse association between attendance to religious services and the perpetration of IPV by both men and women; they also found that men affiliated with conservative Protestant denominations and those who endorsed conservative theological tenets were not more likely than others to perpetrate violence. An analysis of large-scale Canadian data similarly found no differences in men's perpetration of violence by religious denomination (Brinkerhoff et al. 1992). In contrast, a recent qualitative analysis in the U.S. found that religious leaders from Christian, Jewish, and Muslim faiths expressed concerns that religious teachings of male leadership and female submission could be interpreted to support abusive behavior (Levitt and Ware 2006). Numerous other ethnographic studies, based on interviews with various groups including staff at shelters for battered women, IPV survivors, and members of their communities, in the U.S. and other countries (e.g., Giesbrecht and Sevcik 2000; Adelman 2000; Hassouneh-Phillips 2001; Ringel and Bina 2007), suggest that these concerns are legitimate.

More generally, the picture that emerges from the growing body of literature on the religion- IPV linkage at the micro level, within the context of married couples, is that 
it is complex, full of ambiguities and contradictions. Religion can be a constructive force that reduces the risk of both perpetration and victimization; religious beliefs can also help victims flee their abusers. At the same time, conservative theological beliefs -condemning divorce, encouraging traditional gender roles, with husbands in charge of decision making in the home-- have the potential, if misused or taken to an extreme, to contribute to IPV. They can be misinterpreted as sanctioning men's violent acts and can also be a force that encourages women to remain in abusive relationships (Nason-Clark 1997; Nason-Clark and Fisher-Townsend 2000; Nason-Clark 2004).

The present study focuses on women's victimization in dating relationships (as opposed to IPV in the context of marriage). Drawing on the two strands of the literature reviewed above-- at the macro level for the case of Chile, and at the micro level for North-American and other countries, we hypothesize that young Chilean women who grow up in homes with high levels of religious participation (in mostly Catholic and to a lesser extent Evangelical Protestant homes) may be exposed to extreme views and role models, e.g., where the sacredness of family unity is seen as foremost (ruling out divorce even in the face of spousal abuse), or where submissiveness on the part of women is viewed as a key quality-- with such views reinforced by messages from the surrounding social and legal environment. Social learning theory (Bandura 1977) suggests that during childhood and adolescence such women may develop attitudes and beliefs that increase vulnerability to victimization; they may also fail to acquire interpersonal skills related to assertiveness. More specifically, we hypothesize that the generally protective effect for IPV victimization associated with religious participation is absent, or possibly even reversed, at high levels of religious participation. 


\section{Data, Measures, and Methods}

The Survey of Student Well-Being was administered to male and female students at a large, public university in Santiago; all 25 classes corresponding to general education courses offered in the Winter 2005 term were surveyed, except one that was affected by class cancellation. The sample thus obtained included students enrolled in each of the educational programs offered by the university. Total enrollment in the 24 courses was 2,451, but the number of individual students was somewhat smaller as some students (the exact number is unknown) were registered for more than one course. At the time of survey administration, which took place over several weeks, 1,193 students were present in the 24 classes combined, reflecting the typical attendance rate for these classes; 970 students returned completed surveys, an $81 \%$ response rate. Students who had already completed the survey in another class were instructed to not do so again and this accounts for some of the nonresponse. For a detailed description of this data set, see Lehrer et al. (2007a) and Lehrer et al. (2007b).

The present paper utilizes the female sample $(\mathrm{n}=484)$. The analysis excluded 36 cases corresponding to respondents who had never had a date or dating relationship since age 14, along with 7 cases that had missing data on physical violence outcomes, yielding a sample of 441 cases.

Table 1 provides definitions and descriptive statistics for the variables. ${ }^{3}$ The dependent variable measures whether or not the respondent ever experienced physical victimization in a date or dating relationship since age 14 and if so, whether injuries were involved. It is operationalized as a trichotomous variable, equal to 1 if the respondent experienced no incident of physical violence; 2 if she experienced at least one incident of 
physical violence but no injury; and 3 if she experienced at least one incident resulting in injury. This variable was constructed on the basis of a series of questions on incidents of dating violence and related physical injuries addressed to students who had ever had a romantic relationship or gone out on a date since age $14 .{ }^{4}$ Instructions in the survey indicated that any incidents in which the partners were acting in self-defense should be excluded.

The main independent variable in this paper, attendance to religious services at age 14, was coded with six categories in the questionnaire: (a) once week or more often; (b) 2-3 times per month; (c) once a month; (d) several times per year; (e) once or twice per year; and (f) never. Almost a quarter of the sample was in this last category, indicating a relatively high level of secularization in Chilean society.

Data for Chile from the World Values Survey reported by McCleary and Barro (2006) show that $45 \%$ of individuals attend religious services once a month or more often-- closely matching the $42 \%$ figure for the present sample (Table 1 ). According to the 2002 Chilean Census, about 70\% of the population is affiliated with the Catholic faith (although many Catholics in Chile do no practice their religion), about 15\% are Evangelical Protestants, and about 8\% are unaffiliated; Jehovah's Witnesses and Mormons each account for approximately1\% of the population (U.S. Department of State 2003). Information on religious affiliation was not collected in the survey used in the present study.

Family background variables that have been found in earlier studies to be associated with vulnerability to victimization were included as controls. These variables and their effects are discussed at length elsewhere (Lehrer et al. 2007b). Briefly, they 
include dummies for having experienced childhood sexual abuse and for having witnessed domestic violence as a child, low parental education, maternal employment, having been raised in an urban area, and age.

The survey also included information on two choices made by respondents which are expected to affect victimization risk. The first concerns initiating sexual activity; 65\% of the sample had done so. Previous research suggests that dating violence is more prevalent in relationships that include sexual intercourse (Kaestle and Halpern 2005). The second choice is whether to live primarily in the parental home during the college years. It is the norm in Santiago for students to do so, with the exception of students raised in other parts of the country; anecdotal evidence suggests that students raised in Santiago in wealthy families with poor parent-child relations constitute another exception. In the present sample, $78 \%$ of the respondents reported primary residence in the parental home while attending college. This living arrangement is associated with a higher level of social support and supervision, and hence less exposure to the risk of dating violence.

Table 2 provides descriptive statistics suggesting that these choices are related to attendance to religious services. Consistent with results from previous studies (Resnick et al. 1997; Meier 2003), attendance to religious services is significantly associated with a lower likelihood of having initiated sexual activity $(\mathrm{P}<0.01)$. In addition, among students who grew up in an urban area, attendance to religious services is significantly associated with residence in the parental home during the college years $(\mathrm{P}<0.01)$, consistent with findings that relationships between parents and their offspring tend to better when there is shared participation in religious services (Pearce and Axinn 1998). There is no significant association between attendance to religious services and place of residence during the 
college years in the sub- sample who grew up in a small city or rural area-- for most of these respondents, it is likely that the parents still lived away from Santiago when they were attending college.

Multivariate models were estimated using generalized ordered logit. ${ }^{5}$ This procedure utilizes information regarding the order of the categories (i.e., that a violent incident that results in physical injury is more serious than one not involving injury) and allows the proportional odds assumption to be relaxed for variables that fail to meet it.

\section{Results}

The generalized ordered logit estimates for physical victimization since age 14 are presented in Table 3. Brant tests in preliminary analyses indicated that age and maternal employment violated the proportional odds assumption in all models; the corresponding coefficients were therefore allowed to vary across categories. As indicated by the Wald tests, there are no violations of this assumption in the final models.

Briefly commenting first on the family background variables, Models 1 and 2 show that the odds of being victimized are higher for young women raised in homes with low SES, measured by parental education, as compared to their counterparts raised in more privileged homes. Maternal employment is associated with a decreased likelihood of victimization with injury. For the older respondents, ages 21 and over, the odds of having been victimized with injury are almost 5 times the odds for their younger counterparts. Model 3 shows that witnessing domestic violence and experiencing sexual abuse during childhood are each associated with significantly higher odds of victimization. When these childhood violence variables are included, the coefficient on 
low parental education loses significance, suggesting that youth raised in low SES households have higher odds of victimization in late adolescence/ early adulthood in part because they are more likely to have grown up in violent environments. In general, the results on the family background variables are consistent with earlier findings in the literature (Lewis and Fremouw 2001; Vezina and Hebert 2007).

Turning now to attendance to religious services, given the relatively small size of the sample, Model 1 begins by considering four categories which include 20\%, 22\%, $34 \%$, and $24 \%$ of the cases, respectively: high (once a week or more often); moderate (one to three times per month); low (once, twice, or several times per year); and never (the omitted category). In light of the pattern that emerges in this first regression, with the coefficients associated with the moderate and low categories being very close in both magnitude and significance, a combined moderate/ low category is used in the remaining specifications.

Model 2 shows that respondents who had moderate/low levels of attendance to religious services at age 14 have 0.59 the odds of reporting victimization, compared to their counterparts who had zero attendance, consistent with the hypothesis that some participation in religious activities has a protective effect. On the other hand, there is no significant difference in the likelihood of victimization between respondents in the two extremes-- those who grew up with high religious involvement versus none. Since the "high" category includes young women who attended once a week along with those who attended more than once a week, the insignificant coefficient may reflect (a) that attendance at these levels generally has no effect, or (b) a mixture of a beneficial effect for those who attended once a week and an adverse effect for those who attended more 
than once a week. A limitation of the analysis is that it is not possible to ascertain which of these scenarios holds, as the questionnaire did not have separate codes for attendance on a weekly versus a more frequent basis. The religion effects in Model 3, which adds the variables on violence in the childhood environment, are essentially the same as those in Model 2.

Table 4 presents predicted probabilities based on Model 3, illustrating the absolute magnitude of the effect associated with moderate/low religious participation. For a respondent who had typical characteristics for all variables and who reported no attendance to religious services at age 14, the probability of never having been victimized since age 14 is 0.79 . The probability increases to 0.86 for her counterpart who reported a moderate/low level of attendance. The size of this protective effect--7 percentage points-is the same as that of never having witnessed domestic violence as a child, one of the major predictors of vulnerability to dating violence.

Models 4 and 5 add, one at a time, the variables on ever having had sex and residence away from the parental home. While they must be qualified as subject to endogeneity biases, as the sex and residence variables reflect choices made by the students, the results are suggestive. Both of these variables are associated with increased risk of victimization, as expected. In each case, the coefficient on moderate/low attendance to religious services decreases in absolute magnitude and significance compared to Model 3, suggesting that the timing of sexual debut and the choice of place of residence both mediate in part the effect of religiosity: youth who grow up with some religious involvement tend to delay initiation of sexual activity and to remain in the parental home, thus decreasing their vulnerability to dating violence. When both choice 
variables are included in Model 6, the coefficient on moderate/ low attendance becomes statistically insignificant.

As was shown in Table 2, young women who grew up with some religious involvement displayed less risky behaviors in both of the areas documented in the survey-- initiation of sexual activity and place of residence during the college years. It is likely that such women also had more favorable outcomes in other dimensions that are known to be associated with some participation in religious activities, including less use of alcohol and other drugs, and a lower likelihood of having friends with substance use problems. Thus, the association between religious participation and the likelihood of experiencing dating violence shown in Models 1-3 can be interpreted as being explained by the two observed choices made by the students, plus the entire range of unmeasured behaviors that are highly correlated with these choices.

\section{Discussion}

The present study found that young women who grew up with a moderate or low level of attendance to religious services had a smaller likelihood of experiencing dating violence than their counterparts who grew up with no attendance; no significant difference was found between the two extremes, a high level of religious involvement versus none. Overall, these findings are consistent with the hypothesis that the effects of religious participation on young women's wellbeing in the area of IPV victimization are non-linear. Exactly where the boundary is, i.e., at which point additional religious participation stops having a beneficial influence, cannot be ascertained given the limitations of the religious participation variable used in this study. 
This evidence of non-linearities suggests a possible explanation for the seemingly countervailing macro and micro forces in Chile. The influences operating at the macro level-- where the Catholic Church to this date has blocked abortion even in cases of rape or when the woman's health is in danger, and successfully blocked the legalization of divorce until five years ago even in cases of spousal abuse-- have been extreme. Just like religion has the potential to be a positive or an adverse force in the realm of IPV at the micro level, the same is true at the macro level. The teachings of a religion encouraging family harmony and unity, generally a constructive force, become an adverse influence if taken to the extreme of supporting legislation that prohibits divorce.

The non-linear effects uncovered by our estimates can help inform IPV prevention and response programs in Chile. The data used in this paper was based on a survey conducted at a university in Santiago, and 78\% of the subjects reported having grown up in Santiago or another large city. The Church tends to occupy a more dominant role in people's lives in small towns and rural areas, and further research on the complex religion- IPV connection with college students from such locations would be desirable.

This study has several limitations. First, although the sample used in this analysis was broad, covering students enrolled in all educational programs offered by the university, it was not random and the results cannot be generalized to the whole student body. Furthermore, our sample is not representative of Chilean youth-- approximately $46 \%$ of young men and women aged 20-24 in Chile are enrolled in an institution of higher education (IESALC 2006).

Second, the estimates must be qualified as subject to social desirability bias. In their analysis of the linkage between religiosity and the perpetration of IPV, Ellison and 
Anderson (2001) have noted that the generally negative observed relationship between these two variables based on self reports may be spurious, if individuals with a higher need for social approval tend to both overstate their frequency of attendance to religious services, and understate their perpetration of IPV. A similar concern applies here, in connection with IPV victimization, i.e., the present estimates are likely to overstate the generally protective effect of religious participation. Furthermore, if young women with the highest levels of religious participation are likely to both have a high level of victimization and to systematically underreport it, our estimates would fail to capture the positive association between high religious participation and IPV victimization. The fact that our data were collected via self-administered questionnaires rather than interviews alleviates, but does not eliminate, these biases.

Third, the argument developed in this paper is that high levels of religious attendance may be associated with deleterious effects in the domain of IPV, not because of the amount of time devoted to religious activities per se, but rather because such levels tend to be associated with theological views regarding gender inequality, the centrality of male authority in the home, and the sanctity of family unity, that have the potential to be misinterpreted or exaggerated. It is hoped that analyses with richer data on religion, including information on religious affiliation, beliefs on biblical inerrancy, and other religious tenets, will be able to distinguish between effects directly related to religious participation versus those that pertain to other dimensions of religion. Finally, variables that could be used as instruments for religious participation were not available in these data and our estimates must be qualified as subject to possible endogeneity biases. 
The hypothesis that the effects associated with involvement in religious activities are non linear is supported by the present findings regarding the connection between religious participation and women's vulnerability to IPV, and by Chiswick and Huang's (2007) findings regarding the religious participation-earnings linkage. A fruitful avenue for future research would be to explore this hypothesis in connection with other outcomes that have been found to be associated with attendance to religious services, including perpetration of IPV, physical and mental health, youth risk behaviors, and performance in school and educational attainment. The present results suggest that the beneficial effects found in earlier studies for each of these areas may have been driven by cases corresponding to individuals with moderate levels of religious participation. An important question is whether the effects of religious participation are insignificant or possibly adverse at high levels, and future studies should specify the frequency of attendance to religious services variable in a way that permits an answer. The research question "Is religion good for you?" (Gruber 2005) would best be re-stated as "When, in what contexts, is religion good for you?" 


\section{ENDNOTES}

1 Under the law that finally passed in 2004, divorce continues to be a difficult and costly endeavor. Emphasizing the goal of family unity, the law requires a one-year separation period before divorce can be filed, followed by a three-year period in which the parties must go through a mandatory mediation process (Blofield and Haas 2005). 2 Analyses of the data confirmed that, as has been extensively documented for the case of the U.S. and other Western countries (Lewis and Fremouw 2001; Vezina and Hebert 2007), intimate partner violence often begins well before cohabitation and marriage--in dating relationships in late adolescence and young adulthood. The level of such violence in this sample of Chilean college students was found to be similar to that reported in studies based on samples of U.S. college students.

3 To minimize loss of information, the modal category was imputed for cases with missing data for the explanatory variables. Eleven to thirteen cases were imputed for the childhood violence variables; fewer than 8 cases were imputed for each of the other variables, with the exception of the sexual debut variable which had 29 observations with missing data. A missing dummy variable indicator was created for this variable and added to the multivariate models in preliminary analyses; it was insignificant in all models and dropped.

$4 \quad$ Our trichotomous dependent variable makes a distinction between incidents that resulted in physical injuries versus those that did not. The methodological contribution associated with our utilizing information on both scales-- incidents of violence and resulting injuries-- is discussed in the companion paper (Lehrer et al. 2007b).

$5 \quad$ GOLOGIT2 in STATA version 9.2 was employed (Williams 2006). 


\section{REFERENCES}

Adelman, Madelaine. 2000. "No Way Out- Divorce-Related Domestic Violence in Israel." Violence Against Women, 6(11): 1223-1254.

Bahr, Stephen J, Suzanne L. Maughan, Anastasios C. Marcos, Bingdao Li. 1998.

"Family, Religiosity, and the Risk of Adolescent Drug Use." Journal of Marriage and the Family, 60:979-992.

Bandura, A. (1977). Social Learning Theory. New York: General Learning Press.

Bearman, Peter S. and Hannah Bruckner. 2001. "Promising the Future: Virginity Pledges and First Intercourse.” American Journal of Sociology, 106(4): 859-912.

Blofield, Merike H. 2001. The Politics of "Moral Sin:" A Study of Abortion and Divorce in Catholic Chile Since 1990. Santiago, Chile: Flacso. Available at: http://www.unc.edu/ blofield/Flacso\%20publication.pdf (last accessed December 15, 2008).

Blofield, Merike H. and Liesl Haas. 2005. "Defining a Democracy: Reforming the Laws on Women's Rights in Chile, 1990-2002." Latin American Politics and Society, 47(3):35-68.

Brinkerhoff, Merlin B., Elaine Grandin and Eugen Lupri. 1992. "Religious Involvement and Spousal Violence. Journal for the Scientific Study of Religion, 31(1): 15-31.

Casas, Lidia B. 2004. "Women and Reproduction: From Control to Autonomy? The Case of Chile." Journal of Gender, Social Policy and the Law, 12(3):427-451. 
Chiswick, Barry and Jidong Huang. 2007. "The Earnings of American Jewish Men: Human Capital, Denomination, and Religiosity." Presented at the annual meetings of the Illinois Economic Association, Chicago.

Committee on Economic, Social and Cultural Rights. 2004. Shadow Report on the Third Periodic Report of Chile. Presented by La Morada, International Women's Human Rights Law Clinic, and Center for Reproductive Rights. Available at http://www.crlp.org/pdf/sr_chile_1104.pdf (last accessed December 1, 2008).

Donahue, Michael J. and Peter L. Benson. 1995. "Religion and the Well-Being of Adolescents.” Journal of Social Issues, 51(2): 145-160.

Ellison, Christopher and Kristin L. Anderson . 2001. "Religious Involvement and Domestic Violence among U.S. Couples." Journal for the Scientific Study of Religion, 40:269-287.

Ellison, Christopher, John P. Bartkowski and Kristin L. Anderson. 1999. "Are There Religious Variations in Domestic Violence?" Journal of Family Issues, 20(1):87-113.

Foshee, Vangie A. 1996. "Gender Differences in Adolescent Dating Abuse Prevalence, Types and Injuries." Health Education Research, 11:275-286.

Freeman, Richard B. 1986. "Who Escapes? The Relationship of Churchgoing and Other Background Factors to the Socioeconomic Performance of Black Male Youths from Inner-City Tracts.” Pp. 353- 376 in Richard B. Freeman and Harry J. Holzer (eds.) The Black Youth Employment Crisis. Chicago: The University of Chicago Press. 
Giesbrecht, Norman and Irene Sevcik. 2000. "The Process of Recovery and Rebuilding Among Abused Women in the Conservative Evangelical Subculture." Journal of Family Violence, 15(3): 229-248.

Gill, Anthony. 1998. Rendering Unto Caesar: The Catholic Church and the State in Latin America. Chicago and London: The University of Chicago Press.

Gover, Angela R. 2004. "Risky lifestyles and dating violence: A theoretical test of violent victimization." Journal of Criminal Justice, 32:171-180.

Gruber, Jonathan. 2005. "Religious Market Structure, Religious Participation, and Outcomes: Is Religion Good for You?” Advances in Economic Analysis and Policy 5(1): article 5. http://www.bepress.com/bejeap/advances/vol5/iss1/art5 (last accessed December 17, 2008).

Haas, Liesl. 1999. "The Catholic Church in Chile: New Political Alliances." Pp. 43-66 in Christian Smith and Joshua Prokopy (eds.) Latin American Religion in Motion. New York and London: Routledge.

Hassouneh-Phillips, Dena S. 2001. "Marriage is Half of Faith and the Rest is Fear Allah-Marriage and Spousal Abuse Among American Muslims." Violence Against Women, 7(8): 927-946.

Howard Donna, Yue Qiu and Bradley Boekeloo. 2003. "Personal and Social Contextual Correlates of Adolescent Dating Violence." Journal of Adolescent Health, 33:9-17. 
Htun, Mala. 2003. Sex and the State: Abortion, Divorce, and the Family Under Latin American Dictatorships and Democracies. Cambridge: Cambridge University Press.

International Institute for Higher Education in Latin America and the Caribbean (IESALC), 2006. Report on Higher Education in Latin-America and the Caribbean 2000-2005 [in Spanish]. Caracas, Venezuela: IESALC.

Kaestle, Christine E. and Carolyn T. Halpern. 2005. "Sexual Intercourse Precedes Partner Violence in Adolescent Romantic Relationships." Journal of Adolescent Health, 36:386-392.

Koenig Harold G., Michael E. McCullough, David B. Larson. 2001. Handbook of Religion and Health. New York: Oxford University Press.

Lehrer, Evelyn. 2006. "Religion and High School Graduation: A Comparative Analysis of White and Black Young Women.” Review of Economics of the Household, 4(3): 277-293.

Lehrer, Evelyn. 2009. "Religious Affiliation and Participation as Determinants of Women’s Educational Attainment and Wages.” Forthcoming in Christopher Ellison and Robert Hummer (eds.) Religion, Family Life, and Health in the United States, Rutgers University Press.

Lehrer, Jocelyn, Vivian Lehrer, Evelyn Lehrer and Pamela Oyarzun. 2007a. "Prevalence of and Risk Factors for Sexual Victimization in College Women in Chile." International Family Planning Perspectives 33(4): 168-175. 
Lehrer, Jocelyn, Vivian Lehrer, Evelyn Lehrer and Zhenxiang Zhao. 2007b."Physical Dating Violence among College Students in Chile." IZA Discussion Paper \# 2753. Available at http://www.iza.org/ (last accessed December 20, 2008).

Levitt, Heidi M. and Kimberly Ware. 2006. "'Anything with Two Heads is a Monster': Religious Leaders' Perspectives on Marital Equality and Domestic Violence." Violence Against Women, 12:1169-1190.

Lewis, Sarah F. and William Fremouw. 2001. "Dating Violence: A Critical Review of the Literature." Clinical Psychology Review, 21:105-127.

Makepeace, James M. 1987. "Social Factor and Victim-Offender Differences in Courtship Violence." Family Relations, 36:87-91.

Marchena, E. and Waite, L. J. (2002) “Re-Assessing Family Goals and Attitudes in Late Adolescence: The Effects of Natal Family Experiences and Early Family Formation." Pp. 97-127 in R. Lesthaeghe (ed.) Meaning and Choice: Value Orientations and Life Course Decisions. Brussels: The Netherlands Interdisciplinary Demographic Institute.

McCleary, Rachel M. and Robert J. Barro. 2006. "Religion and Economy." Journal of Economic Perspectives, 20(2): 49-72.

McWhirter, Paula T. 1999. "La Violencia Privada: Domestic Violence in Chile." American Psychologist, 54(1): 37-40.

Meier AM. 2003. "Adolescents' Tansition to First Intercourse, Religiosity, and Attitudes about Sex." Social Forces, 81(3):1031-1052. 
Muller, Chandra and Christopher G. Ellison. 2001. "Religious Involvement, Social Capital, and Adolescents’ Academic Progress: Evidence from the National Education Longitudinal Study of 1988.” Sociological Focus, 34(2): 155-183.

Nason-Clark, Nancy. 1997. The Battered Wife-- How Christians Confront Family Violence. Louisville: Westminster John Knox Press.

Nason-Clark, Nancy. 2004. "When Terror Strikes at Home: The Interface between Religion and Domestic Violence." Journal for the Scientific Study of Religion, 43(3): 303-310.

Nason-Clark, Nancy and Barbara Fisher-Townsend. 2000. "Gender." Pp. 207-226 in Helen Rose Ebaugh (ed.) Handbook of Religion and Social Institutions. New York: Springer.

Neuwirth, Jessica. 2005. "Inequality before the Law: Holding States Accountable for Sex Discriminatory Laws Under the Convention on the Elimination of All Forms of Discrimination Against Women and through the Beijing Platform for Action." Harvard Human Rights Journal, 18(Spring). Available at http://www.law.harvard.edu/students/orgs/hrj/iss18/neuwirth.shtml (last accessed December 15, 2008).

Pearce, Lisa D. and William G. Axinn. 1998. “The Impact of Family Religious Life on the Quality of Mother-Child Relations.” American Sociological Review, 63: 810-828. 
Regnerus, Mark D. 2000. “Shaping Schooling Success: Religious Socialization and Educational Outcomes in Metropolitan Public Schools.” Journal for the Scientific Study of Religion, 39: 363-370.

Resnick MD, Bearman PS, Blum RW, et al. 1997. " Protecting Adolescents from Harm: Findings from the National Longitudinal Study on Adolescent Health." Journal of the American Medical Association, 278: 823-832.

Ringel, Shoshana and Rena Bina. 2007. "Understanding Causes of and Responses to Intimate Partner Violence in a Jewish Orthodox Community: Survivors' and Leaders' Perspectives." Research on Social Work Practice, 17(2): 277-286.

Smith, Christian. 2003. "Theorizing Religious Effects Among American Adolescents." Journal for the Scientific Study of Religion, 42(1): 17-30.

Straus, Murray A, SL Hamby , WL Warren. 2003. The Conflict Tactics Scales Handbook: Revised Conflict Tactics Scale (CTS2); CTS: Parent-Child Version (CTSPC). Los Angeles, CA: Western Psychological Services.

U. S. Department of State. 2003. International Religious Freedom Report. Available at http://www.state.gov/g/drl/rls/irf/2003/24483.htm (last accessed December 1, 2008).

Vezina, Johanne and Martine Hebert. 2007. "Risk Factors for Victimization in Romantic Relationships of Young Women: A Review of Empirical Studies and Implications for Prevention." Trauma Violence Abuse, 8:33-66. 
Waite, Linda and Evelyn Lehrer. 2003. "The Benefits from Marriage and Religion in the United States: A Comparative Analysis.” Population and Development Review, 29(2): 255-275.

Williams, RA. 2006. "Generalized Ordered Logit/ Partial Proportional Odds Models for Ordinal Dependent Variables." The Stata Journal, 6:58-82. 
Table 1. Variable Definitions and Descriptive Statistics

\begin{tabular}{|c|c|c|}
\hline Variable & Definition & $\begin{array}{l}\text { Descriptive } \\
\text { Statistics }^{\mathrm{a}} \\
\end{array}$ \\
\hline \multicolumn{3}{|l|}{$\begin{array}{l}\text { Physical victimization } \\
\text { since age } 14\end{array}$} \\
\hline $\begin{array}{l}\text { No incidents } \\
\text { (dependent variable }=1 \text { ) }\end{array}$ & $\begin{array}{l}\text { Respondent }(\mathrm{R}) \text { indicates that since age } 14 \text { she never } \\
\text { experienced a violent incident }{ }^{\mathrm{b}}\end{array}$ & 0.74 \\
\hline $\begin{array}{l}\text { Violence with no injury } \\
\text { (dependent variable }=2 \text { ) }\end{array}$ & $\begin{array}{l}\mathrm{R} \text { indicates that since age } 14 \text { she experienced at least } \\
\text { one violent incident, with no injuries }{ }^{\mathrm{C}}\end{array}$ & 0.21 \\
\hline $\begin{array}{l}\text { Violence with injury } \\
\text { (dependent variable = 3) }\end{array}$ & $\begin{array}{l}\mathrm{R} \text { indicates that since age } 14 \text { she experienced at least } \\
\text { one violent incident that resulted in injury }{ }^{\mathrm{C}}\end{array}$ & 0.05 \\
\hline $\begin{array}{l}\text { Attendance at religious } \\
\text { services }\end{array}$ & $\begin{array}{l}=1 \text { if response is in category indicated } \\
\text { (Reference category is "never") }\end{array}$ & \\
\hline Once a week or more & & 0.20 \\
\hline 2-3 times per month & & 0.15 \\
\hline Once a month & & 0.07 \\
\hline Several times per year & & 0.16 \\
\hline Once or twice per year & & 0.18 \\
\hline Never & & 0.24 \\
\hline \multicolumn{3}{|l|}{$\begin{array}{l}\text { Control variables } \\
\text { Family Background } \\
\text { Variables }\end{array}$} \\
\hline $\begin{array}{l}\text { Experienced childhood } \\
\text { sexual abuse }\end{array}$ & $\begin{array}{l}=1 \text { if } \mathrm{R} \text { responded affirmatively to at least one of the } \\
\text { following questions: "Before age } 14 \text {, did someone } \\
\text { ever make you have sex against your will?" and } \\
\text { "Before age } 14 \text {, did you ever have any other form of } \\
\text { unwanted sexual experience, such as forced kisses, } \\
\text { grabbing, etc.?" }\end{array}$ & 0.21 \\
\hline $\begin{array}{l}\text { Witnessed domestic } \\
\text { violence }\end{array}$ & $\begin{array}{l}=1 \text { if, before age } 14 \text {, } \mathrm{R} \text { had ever witnessed violence } \\
\text { between her parents or other adults who raised her }\end{array}$ & 0.36 \\
\hline Low parental education & $\begin{array}{l}=1 \text { if the highest level of education attained by } \\
\text { parents or other adults who raised R was } 12 \\
\text { years of regular schooling or less, or incomplete } \\
\text { advanced technical schooling or less }\end{array}$ & 0.30 \\
\hline Large city & $\begin{array}{l}=1 \text { if } \mathrm{R} \text { resided in Santiago or another large urban } \\
\text { area at age } 14\end{array}$ & 0.78 \\
\hline Maternal employment & $\begin{array}{l}=1 \text { if R's mother worked outside the home when she } \\
\text { was } 14\end{array}$ & 0.61 \\
\hline Age $\geq 21$ & $\begin{array}{l}=1 \text { if } \mathrm{R} \text { was } 21 \text { years of age or older at the time of } \\
\text { the survey }\end{array}$ & 0.37 \\
\hline
\end{tabular}


Table 1 (Continued)

\begin{tabular}{llc}
\hline Variable & Definition & $\begin{array}{l}\text { Descriptive } \\
\text { Statistics }^{\mathbf{a}}\end{array}$ \\
\hline Ever had sex & $=1$ if R reported ever having had voluntary sex & 0.65 \\
$\begin{array}{l}\text { Residence away from } \\
\text { parents }\end{array}$ & $=1$ if R had primarily resided outside of the & 0.22 \\
& home since enrolling in the university
\end{tabular}

$$
\mathrm{n}=441
$$

a The statistics reported here are means for the explanatory variables and the proportion in each category for the dependent variable.

b The items on violence, adapted from a scale used by Foshee (1996), included questions on whether the subject reports that her partner ever did one of the following things before age 14: scratched or slapped me; pushed, grabbed, or shoved me; slammed me or held me against the wall; kicked or bit me; hit me with a fist; hit me with something hard; beat me repeatedly; tried to choke me; burned me, assaulted me with a knife or gun. A violent incident was defined as an affirmative answer to any of the above questions.

${ }^{\mathrm{c}}$ Physical injury was defined as occurring if the subject indicated that one of the following things ever happened to her before age 14: "I had a sprain, bruise or small cut because of a fight with a partner;" "I passed out from being hit on the head by my partner in a fight;" "I went to a doctor for an injury from a fight with my partner;" or "I needed to see a doctor for an injury from a fight with my partner, but didn't go." These items were adapted from a scale developed by Straus et al. (2003). 
Table 2. The Association of Frequency of Attendance to Religious Services with Sexual Debut and Living Arrangements

\begin{tabular}{|c|c|c|c|}
\hline & \% who ever had sex & $\%$ who lived at & y from parents \\
\hline & Full sample & $\begin{array}{l}\text { Respondents raised } \\
\text { in large city }\end{array}$ & $\begin{array}{c}\text { Respondents raised } \\
\text { in small city/ } \\
\text { rural area }\end{array}$ \\
\hline & $n=441$ & $n=342$ & $n=99$ \\
\hline $\begin{array}{l}\text { High attendance } \\
\text { (once a week or } \\
\text { more) }\end{array}$ & $54.55 \%$ & $2.90 \%$ & $78.95 \%$ \\
\hline $\begin{array}{l}\text { Moderate/low } \\
\text { attendance } \\
\text { (less than once a } \\
\text { week) }\end{array}$ & $63.97 \%$ & $6.38 \%$ & $71.19 \%$ \\
\hline $\begin{array}{l}\text { No attendance } \\
\text { (never) }\end{array}$ & $75.47 \%$ & $15.29 \%$ & $52.38 \%$ \\
\hline$\chi 2$ (P-value, df) & $\begin{aligned} & 9.43 \\
&(<0.01,2) \\
&\end{aligned}$ & $\begin{array}{c}9.36 \\
(<0.01,2) \\
\end{array}$ & $\begin{array}{c}3.70 \\
(0.16,2) \\
\end{array}$ \\
\hline
\end{tabular}


Table 3. Generalized Ordered Logit Estimates--The Effects of Attendance to Religious Services and Controls on the Odds of Dating Violence Victimization. Coefficient (SE) [Odds ratio]

\begin{tabular}{|c|c|c|c|c|c|c|}
\hline \multirow{2}{*}{\multicolumn{2}{|c|}{$\begin{array}{l}\text { Model } 1 \\
\text { Attendance to religious } \\
\text { services }^{\text {a }}\end{array}$}} & \multirow[t]{2}{*}{ Model 2} & \multirow[t]{2}{*}{ Model 3} & \multirow[t]{2}{*}{ Model 4} & \multirow[t]{2}{*}{ Model 5} & \multirow[t]{2}{*}{ Model 6} \\
\hline & & & & & & \\
\hline High & $\begin{array}{l}-0.37(0.33) \\
{[0.69]}\end{array}$ & $\begin{array}{l}-0.37(0.33) \\
{[0.69]}\end{array}$ & $\begin{array}{l}-0.36(0.33) \\
{[0.69]}\end{array}$ & $\begin{array}{l}-0.28(0.33) \\
{[0.76]}\end{array}$ & $\begin{array}{l}-0.32(0.33) \\
{[0.72]}\end{array}$ & $\begin{array}{l}-0.24(0.34) \\
{[0.79]}\end{array}$ \\
\hline Moderate & $\begin{array}{l}-0.55(0.32)^{\star} \\
{[0.58]}\end{array}$ & & & & & \\
\hline Low & $\begin{array}{l}-0.51(0.29)^{\star} \\
{[0.60]}\end{array}$ & & & & & \\
\hline Moderate/Low & & $\begin{array}{l}-0.52(0.26)^{\star \star} \\
{[0.59]}\end{array}$ & $\begin{array}{l}-0.52(0.26)^{\star \star} \\
{[0.60]}\end{array}$ & $\begin{array}{l}-0.48(0.26)^{*} \\
{[0.62]}\end{array}$ & $\begin{array}{l}-0.47(0.27)^{*} \\
{[0.63]}\end{array}$ & $\begin{array}{l}-0.43(0.27) \\
{[0.65]}\end{array}$ \\
\hline \multicolumn{7}{|l|}{ Other variables } \\
\hline $\begin{array}{l}\text { Experienced childhood } \\
\text { sexual abuse }\end{array}$ & & & $\begin{array}{l}0.65(0.25)^{\star \star} \\
{[1.91]}\end{array}$ & $\begin{array}{l}0.62(0.26)^{\star \star} \\
{[1.86]}\end{array}$ & $\begin{array}{l}0.66(0.26)^{\star \star \star} \\
{[1.93]}\end{array}$ & $\begin{array}{l}0.63(0.26)^{\star \star} \\
{[1.88]}\end{array}$ \\
\hline $\begin{array}{l}\text { Witnessed domestic } \\
\text { violence }\end{array}$ & & & $\begin{array}{l}0.53(0.23)^{\star \star} \\
{[1.70]}\end{array}$ & $\begin{array}{l}0.49(0.23)^{\star \star} \\
{[1.64]}\end{array}$ & $\begin{array}{l}0.46(0.23)^{\star \star} \\
{[1.58]}\end{array}$ & $\begin{array}{l}0.42(0.24)^{*} \\
{[1.52]}\end{array}$ \\
\hline Low parental education & $\begin{array}{l}0.41(0.23)^{\star} \\
{[1.50]}\end{array}$ & $\begin{array}{l}0.41(0.23)^{*} \\
{[1.50]}\end{array}$ & $\begin{array}{l}0.25(0.24) \\
{[1.28]}\end{array}$ & $\begin{array}{l}0.31(0.24) \\
{[1.36]}\end{array}$ & $\begin{array}{l}0.31(0.24) \\
{[1.36]}\end{array}$ & $\begin{array}{l}0.37(0.25) \\
{[1.45]}\end{array}$ \\
\hline Large city & $\begin{array}{l}0.38(0.28) \\
{[1.46]}\end{array}$ & $\begin{array}{l}0.38(0.28) \\
{[1.46]}\end{array}$ & $\begin{array}{l}0.39(0.29) \\
{[1.48]}\end{array}$ & $\begin{array}{l}0.37(0.29) \\
{[1.45]}\end{array}$ & $\begin{array}{l}0.78(0.36)^{\star \star} \\
{[2.17]}\end{array}$ & $\begin{array}{l}0.76(0.37)^{\star \star} \\
{[2.13]}\end{array}$ \\
\hline \multicolumn{7}{|l|}{ Maternal employment } \\
\hline 1 vs. $2 \& 3$ & $\begin{array}{l}-0.29(0.23) \\
{[0.75]}\end{array}$ & $\begin{array}{l}-0.29(0.23) \\
{[0.75]}\end{array}$ & $\begin{array}{l}-0.36(0.23) \\
{[0.70]}\end{array}$ & $\begin{array}{l}-0.40(0.24)^{*} \\
{[0.67]}\end{array}$ & $\begin{array}{l}-0.34(0.24) \\
{[0.71]}\end{array}$ & $\begin{array}{l}-0.38(0.24) \\
{[0.68]}\end{array}$ \\
\hline $1 \& 2$ vs. 3 & $\begin{array}{l}-1.27(0.46)^{\star \star \star} \\
{[0.28]}\end{array}$ & $\begin{array}{l}-1.27(0.46)^{\star \star \star} \\
{[0.28]}\end{array}$ & $\begin{array}{l}-1.35(0.47)^{\star \star \star} \\
{[0.26]}\end{array}$ & $\begin{array}{l}-1.39(0.47)^{\star \star \star} \\
{[0.25]}\end{array}$ & $\begin{array}{l}-1.34(0.47)^{\star \star \star} \\
{[0.26]}\end{array}$ & $\begin{array}{l}-1.38(0.47)^{\star \star \star} \\
{[0.25]}\end{array}$ \\
\hline \multicolumn{7}{|l|}{ Age $>=21$} \\
\hline 1 vs. $2 \& 3$ & $\begin{array}{l}0.29(0.23) \\
{[1.33]}\end{array}$ & $\begin{array}{l}0.29(0.23) \\
{[1.33]}\end{array}$ & $\begin{array}{l}0.22(0.23) \\
{[1.24]}\end{array}$ & $\begin{array}{l}0.09(0.24) \\
{[1.09]}\end{array}$ & $\begin{array}{l}0.16(0.23) \\
{[1.18]}\end{array}$ & $\begin{array}{l}0.03(0.24) \\
{[1.03]}\end{array}$ \\
\hline $1 \& 2$ vs. 3 & $\begin{array}{l}1.59(0.49)^{\star \star \star} \\
{[4.92]}\end{array}$ & $\begin{array}{l}1.59(0.49)^{\star \star \star} \\
{[4.91]}\end{array}$ & $\begin{array}{l}1.56(0.49)^{\star \star \star} \\
{[4.75]}\end{array}$ & $\begin{array}{l}1.43(0.49)^{\star \star \star} \\
{[4.18]}\end{array}$ & $\begin{array}{l}1.49(0.49)^{\star \star \star} \\
{[4.42]}\end{array}$ & $\begin{array}{l}1.36(0.50)^{\star \star \star} \\
{[3.90]}\end{array}$ \\
\hline Ever had sex & & & & $\begin{array}{l}0.55(0.26)^{\star *} \\
{[1.73]}\end{array}$ & & $\begin{array}{l}0.54(0.26)^{\star *} \\
{[1.72]}\end{array}$ \\
\hline Residence away from pa & & & & & $\begin{array}{l}0.64(0.34)^{*} \\
{[1.90]}\end{array}$ & $\begin{array}{l}0.64(0.35)^{\star} \\
{[1.89]}\end{array}$ \\
\hline $\log L$ & -291.64 & -291.65 & -285.45 & -283.21 & -283.72 & -281.54 \\
\hline $\begin{array}{l}X^{2} \\
(P \text { value, } d f)\end{array}$ & $\begin{array}{l}27.96 \\
(<0.01,9)\end{array}$ & $\begin{array}{l}30.04 \\
(<0.01,8)\end{array}$ & $\begin{array}{l}42.45 \\
(<0.01,10)\end{array}$ & $\begin{array}{l}46.93 \\
(<0.01,11)\end{array}$ & $\begin{array}{l}45.90 \\
(<0.01,11)\end{array}$ & $\begin{array}{l}50.26 \\
(<0.01,12)\end{array}$ \\
\hline $\begin{array}{l}\text { Wald test } \\
\text { ( } P \text { value, } d f)\end{array}$ & $\begin{array}{l}5.99 \\
(0.31,5)\end{array}$ & $\begin{array}{l}5.15 \\
(0.27,4)\end{array}$ & $\begin{array}{l}4.98 \\
(0.55,6)\end{array}$ & $\begin{array}{l}5.37 \\
(0.61,7)\end{array}$ & $\begin{array}{l}5.17 \\
(0.64,7)\end{array}$ & $\begin{array}{l}5.48 \\
(0.71,8)\end{array}$ \\
\hline
\end{tabular}

${ }^{\mathrm{a}}$ The reference category in all models is no attendance to religious services. $\mathrm{n}=441$ $* * * \mathrm{P}<0.01 ; * * \mathrm{P}<0.05 ; * \mathrm{P}<0.10$ 
Table 4. Predicted Probabilities of No Victimization, Victimization with No Injury, and Victimization with Injury for Selected Values of Independent Variables (based on Model 3 in Table 3)

\begin{tabular}{llll}
\hline & $\mathrm{P}_{1}{ }^{\mathrm{a}}$ & $\mathrm{P}_{2}$ & $\mathrm{P}_{3}$ \\
\hline Reference person $^{\mathrm{b}}$ & 0.86 & 0.13 & 0.01 \\
\hline Attendance to religious services & & & \\
High & $(0.84)^{\mathrm{c}}$ & $(0.15)$ & $(0.01)$ \\
None & 0.79 & 0.20 & 0.01 \\
Experienced childhood sexual abuse & 0.77 & 0.22 & 0.01 \\
Witnessed domestic violence & 0.79 & 0.20 & 0.01 \\
Low parental education & $(0.83)$ & $(0.16)$ & $(0.01)$ \\
Living in small city/ rural area & $(0.90)$ & $(0.09)$ & $(0.01)$ \\
Mother not employed & 0.82 & 0.16 & 0.02 \\
Age $\geq 21$ & 0.83 & 0.14 & 0.03 \\
\hline
\end{tabular}

$$
\mathrm{n}=441
$$

${ }^{a} \mathrm{P}_{1}, \mathrm{P}_{2}$, and $\mathrm{P}_{3}$ represent the predicted probabilities of no victimization, victimization with no injury, and victimization with injury, respectively.

${ }^{\mathrm{b}}$ The reference person has the modal characteristics: moderate/low attendance to religious services; never experienced child abuse; never witnessed domestic violence; high parental education; grew up in big city; mother employed; age under 21. Other probabilities are based on the same characteristics, except as noted in the stub.

${ }^{\mathrm{c}}$ Estimates based on insignificant coefficients $(\mathrm{P}<0.10)$ are shown in parentheses. 